\title{
DEMETRIDA (COLEOPTERA: CARABIDAE) IN THE MOLUCCAS*
}

\author{
By P. J. Darlington, Jr. \\ Museum of Comparative Zoology
}

Demetrida is a genus of the carabid tribe Lebiini recognizable by usually rather slender form (Figs. I, 2); moderate size (5.5 - I2.0 $\mathrm{mm}$ in New Guinea) ; brown, bicolored, or brilliant metallic coloration; and technical characters given by me in I968. Although a few species occur in New Zealand and New Caledonia, the genus is dominant primarily in Australia and New Guinea. The principal habitats occupied on these two adjacent land masses are surprisingly different. In Australia, adults (I do not know the larvae) of most species live on the trunks of eucalypts and other trees; in New Guinea, most live in understory foliage of rain forest. (In New Guinea, Demetrida therefore occupies the niche that Calleida occupies in some other parts of the world.) Some New Guinean Demetrida occur in the lowlands, but more, including most of the brilliant ones, are found at moderate or sometimes high altitudes in the mountains. The New Guinean members of the genus seem to have radiated independently of the Australian forms. Their radiation is in some ways compared to that of the brilliant birds of paradise that live in the same montane rain forests.

When I revised the New Guinean species (1968), I stated that the genus reached the Moluccas but did not give details. I now record the two species known from these islands. They set the western limit of the genus in the Indo-Australian Archipelago.

\section{Demetrida latangula Darlington (Fig. I)}

Darlington 1968, pp. 147, 158.

Occurrence in the Moluccas: I $\sigma^{\pi}$. "Amboina, F. Muir" (Bishop Museum).

This species is widely distributed at low altitudes in New Guinea, although not common there. The Moluccan individual matches New Guinean ones well.

Demetrida moluccensis n. sp. (Fig. 2)

Description. With characters of genus (Darlington 1968); form as in Fig. 2, rather convex; dark reddish brown, appendages somewhat paler; not pubescent, moderately shining, reticulate micro-

*Manuscript received by the editor September 1, 1968 

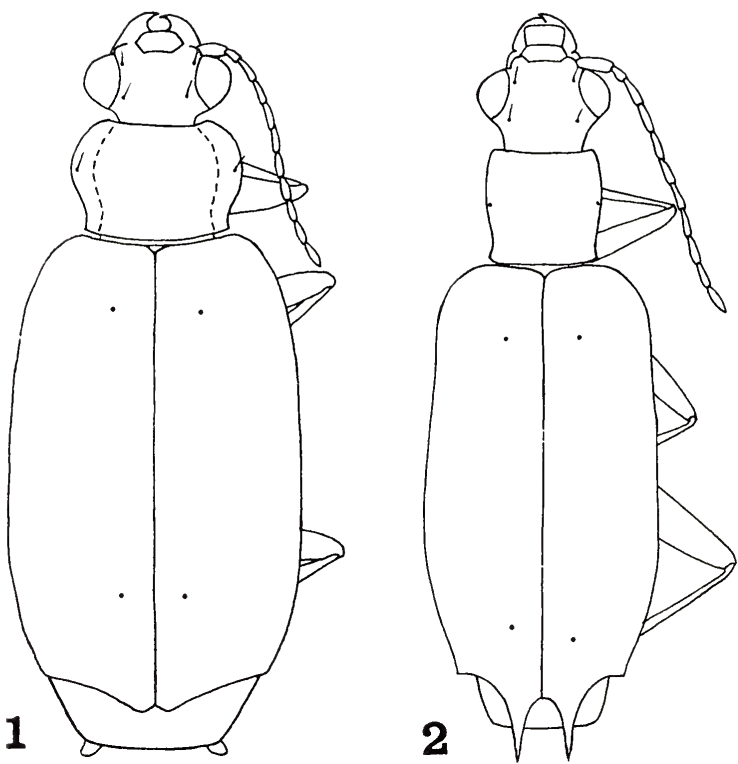

Fig. 1. Demetrida latangula Darlington

Fig. 2. Demetrida moluccensis n. sp.

sculpture indistinct on head and pronotum, light and imperfect on elytra. Head I.IO and I.O3 width prothorax; eyes normal, prominent, genae short and oblique; front nearly flat, slightly irregularly impressed between eyes especially at sides. Prothorax quadrate; width/length I.03 and I.05; base/apex I.I7 and I.I5; base/head 0.83 and 0.83 ; margins narrow, each with seta-bearing puncture at middle but none at base; disc with middle line well impressed, transverse impressions very weak, baso-lateral impressions weak, they and marginal areas punctate; disc otherwise virtually impunctate but faintly transversely stringulose. Elytra: width elytra/prothorax 2.05 and I.98; apices with outer angles well defined, right or slightly obtuse, then broadiy emarginate to long spines $c$. opposite 3 rd intervals, then emarginate to obtuse sutural angles; striae well impressed, scarcely punctulate; intervals somewhat convex, 3rd 2-punctate. Inner wings fully developed. Lower surface not distinctly punctate. Legs: claws each with $c .6$ long teeth. Secondary sexual characters: $\sigma^{\pi}$ front tarsi narrowly biseriately squamulose ( as usual in genus); $\sigma^{\top}$ middle tibiae nearly straight, briefly tuberculate-serrate ( $c .3$ tubercles) distally on inner edge; $\sigma^{\star}$ with 29 apparently 3 seta- 
bearing punctures each side last ventral segment. Measurements: length 8.6-8.8 (including spines); width $2.9 \mathrm{~mm}$.

Types. Holotype $\sigma^{\pi}$ (British Mus.) and I (probably \&) paratype (MCZ Type No. 31,672) both from Laboean, Batjan Is., Moluccas, Feb., Mar. (no year given) (Doherty).

Notes. In my key to the species of Demetrida of New Guinea ( I968, pp. I46ff) this runs to couplet 35 but fits neither species there named, having the prothorax more quadrate than in forma Darlington and the $\sigma^{\pi}$ middle tibiae less bent in at apex than in recta Darlington and tuberculate-serrate (not so in recta).

The specimens here described were seen by Liebke, who labeled them "Genus? spec.?"

\section{REFERENCE}

Darlington, P. J., JR.

1968. The carabid beetles of New Guinea. Part III. Harpalinae (continued): Perigonini to Pseudomorphini. Bull. Mus. Comp. Zool. 137 (1) : 1-253 (Demetrida, pages 140-183). 


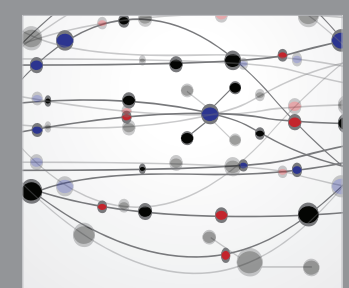

The Scientific World Journal
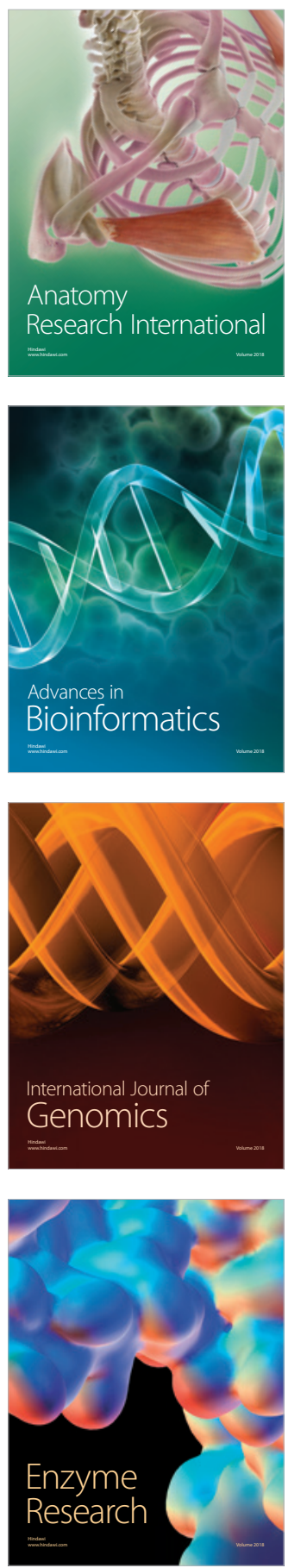
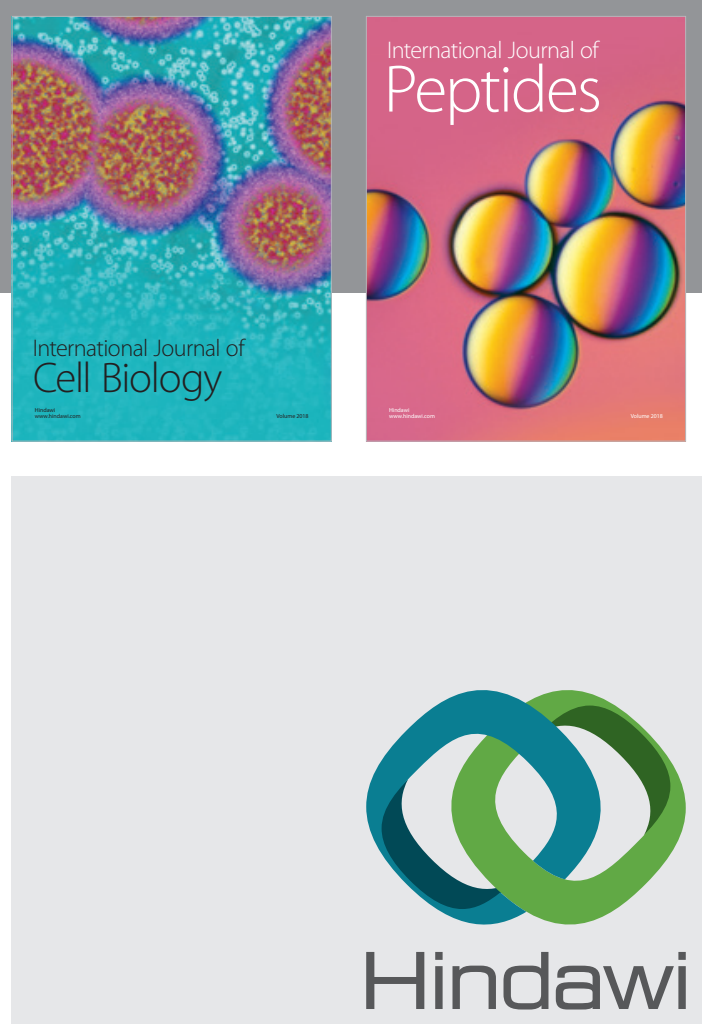

Submit your manuscripts at

www.hindawi.com
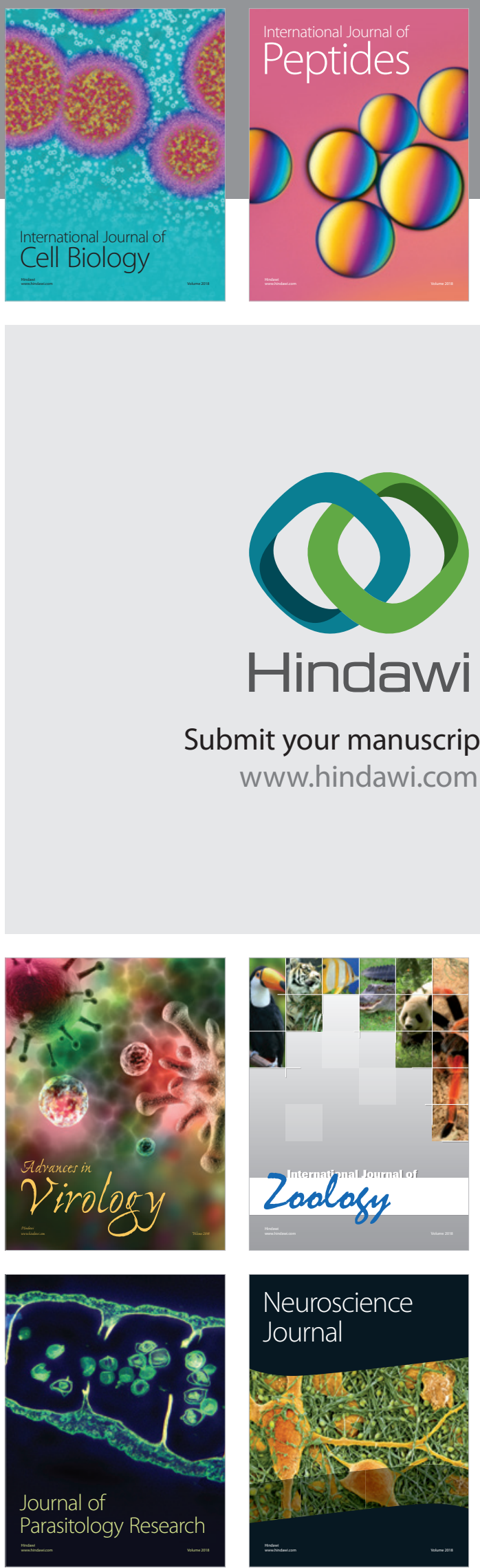
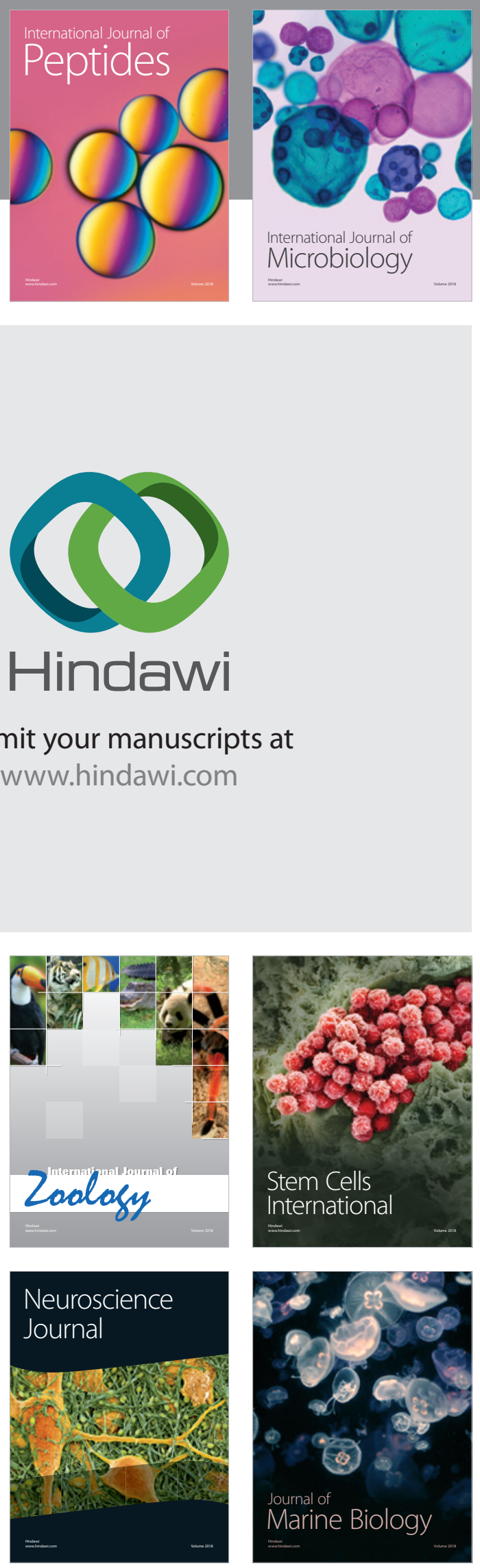
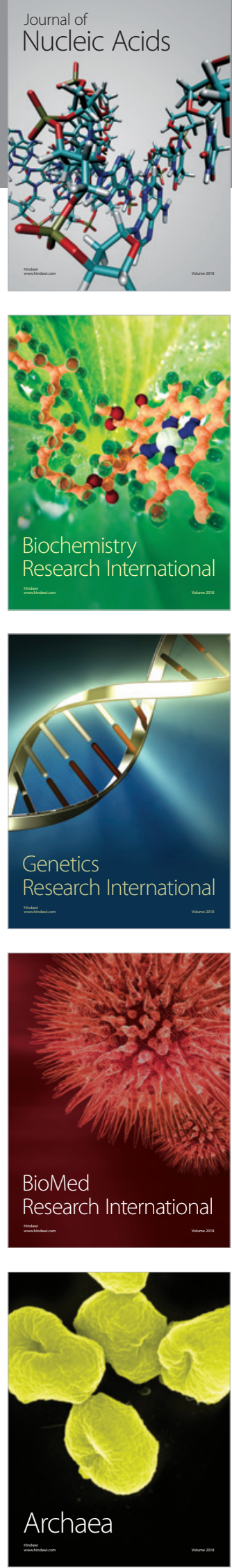